\title{
ANALISIS KESALAHAN SISWA SMP DALAM MEMBUAT PEMODELAN MATEMATIKA
}

\author{
Masfiyah $^{1 *}$, Ali Shodikin ${ }^{2}$ \\ ${ }^{1,2}$ Prodi Pendidikan Matematika Fakultas Keguruan dan Ilmu Pendidikn, Universitas Islam Darul Ulum \\ Jalan Airlangga No. 03 Sukodadi, Lamongan, 62253, Indonesia \\ e-mail: ${ }^{1}$ mfiyah92@gmail.com; ${ }^{2}$ alishodikin@unisda.ac.id;
}

Submitted: February 6,2021

Revised: April 5, 2021

Accepted: May 16, 2021

corresponding author*

\begin{abstract}
Abstrak
Pemodelan merupakan tahap penting dalam penyelesaian masalah matematika, terutama pada jenis soal cerita. Namun demikian, proses pemodelan seringkali menjadi masalah utama bagi siswa. Tujuan penelitian adalah untuk mendeskripsikan kesalahan siswa SMP dalam membuat pemodelan matematika dan faktor yang menyebabkan terjadinya kesalahan tersebut. Penelitian ini adalah penelitian kualitatif dengan menggunakan pendekatan deskriptif pada siswa kelas VIII SMP Negeri 2 Modo, Lamongan pada semester Ganjil Tahun Ajaran 2020/2021. Teknik pengumpulan data yang dilakukan berupa tes dan wawancara. Hasil penelitian ini menunjukkan bahwa kesalahan yang terjadi adalah siswa tidak dapat mengidentifikasi variabel-variabel soal, membuat asumsi yang salah, dan membentuk persamaan yang tidak mewakili masalah. Penyebab internal kesalahan tersebut adalah tidak memahami komponen-komponen masalah, menggunakan nalar atau insting sendiri dalam menyelesaikan soal cerita, tidak memperhatikan keterkaitan antar komponen masalah. Sedangkan faktor eksternalnya adalah tingkat kesulitan soal yang diberikan cukup tinggi dan kurangnya sumber referensi yang memadai.
\end{abstract}

Kata Kunci: analisis kesalahan, penyebab, membuat model, pemodelan matematis

\section{ANALYSIS OF ERRORS OF JUNIOR HIGH SCHOOL STUDENTS IN SOLVING MATHEMATICAL MODELING PROBLEMS}

\begin{abstract}
Modeling is an important stage in solving mathematical problems, especially in the type of story problem. However, the modeling process is often a major problem for students. The research objective was to describe the mistakes of junior high school students in making mathematical modeling and the factors that caused these errors. This research is a qualitative research using a descriptive approach in class VIII students of SMP Negeri 2 Modo, Lamongan in the odd semester of the 2020/2021 academic year. Data collection techniques were carried out in the form of tests and interviews. The results of this study indicate that the errors that occur are students cannot identify the question variables, make wrong assumptions, and form equations that do not represent the problem. The internal causes of this error are not understanding the components of the problem, using reason or instinct to solve the story problem, not paying attention to the relationship between the components of the problem. While the external factor is the level of difficulty of the questions given is quite high and the lack of adequate reference sources.
\end{abstract}

Keywords: error analysis, causative factor, making models, mathematical modeling

\section{Pendahuluan}

Belajar matematika tidak hanya menuntut pelajar untuk pandai berhitung tetapi juga harus bisa mengaplikasikannya ke dunia nyata secara bermakna. Pernyataan ini bisa dipandang sebagai hubungan implikasi dua arah antara matematika dan dunia nyata, yakni matematika untuk dunia nyata dan dunia nyata untuk matematika. Matematika untuk dunia nyata dapat diartikan sebagai implementasi matematika dalam menyelesaikan maupun menjelaskan fenomenafenomena ataupun masalah-masalah dalam dunia nyata. Sedangkan dunia nyata untuk matematika dapat dimaknai sebagai realisasi konsep matematika dalam dunia nyata dan dalam proses mempelajari matematika secara kontekstual dan bermakna.

Menghubungkan matematika dengan dunia nyata tidak dapat dilepaskan dari peran pemodelan matematika. Pemodelan matematika merupakan jembatan penting dalam menyelesaikan soal kontekstual atau masalah matematika dalam dunia nyata. Masalah matematika diubah terlebih dahulu menjadi masalah matematika, selanjutnya 
diselesaikan dengan cara matematis, hasilnya akan diartikan lagi sebagai masalah dari dunia nyata. Pemodelan merupakan aspek penting yang merepresentasikan masalah secara terstruktur baik simbolik maupun variabel dari dunia nyata ke dalam bentuk matematis. Pemodelan matematika merupakan penyajian masalah dunia nyata ke dalam dunia matematika (Dym \& Ivey, 2004). Pemodelan matematika adalah salah satu cara menguraikan persoalan kompleks ke dalam bentuk matematika (Ndii, 2018). Pemodelan matematika juga disebut sebagai bentuk simbolik masalahmasalah yang berbentuk soal cerita (Widowati dan Sutimin, 2017).

Proses mengubah atau mewakili masalah dalam dunia nyata ke dalam bentuk matematika dalam upaya untuk menemukan solusi dari suatu masalah disebut dengan pemodelan matematika (Ang, 2019). Namun demikian, Shodikin, dkk. (2019b) menunjukkan bahwa proses pemodelan matematis yang dilakukan siswa dalam menyelesaikan masalah tidak selalu mengikuti siklus pemodelan matematis yang ideal.

Proses memodelkan dari masalah nyata ke konteks matematika sering kali dikenal sebagai istilah matematisasi. Menurut Amala, \& Ekawati (2016), ada dua jenis matematisasi yaitu matematisasi horizontal dan matematisasi vertikal. Matematisasi horizontal adalah mengubah dunia nyata ke bentuk matematika, sedangkan matematisasi vertikal adalah proses yang terjadi di dalam sistem matematika itu sendiri. Jika pelajar belajar matematika tanpa melibatkan kehidupan sehari-hari maka siswa akan cepat lupa dan tidak dapat mengaplikasikan matematika (Nuryadi 2014). Pembelajaran yang tidak melibatkan kehidupan nyata akan menjadi kurang bermakna dan berlaku sebaliknya jika pembelajaran yang melibatkan pengalaman di dunia nyata akan meningkatkan motivasi siswa dalam belajar.

Pembelajaran matematika dengan pemodelan matematika akan membuat siswa berpikir logis. Bentuk soal pemodelan biasanya bersifat pemecahan masalah nyata dalam bentuk soal cerita. Namun demikian, siswa mengalami kesulitan-kesulitan dalam mengaplikasikan matematika ke dalam konteks kehidupan nyata yang mengantarkan pada kesalahan siswa (Rohmawati 2013).

Bentuk soal pemodelan matematika umumnya berbentuk soal cerita. Kesalahan siswa dalam menyelesaikan soal cerita umumnya disebabkan oleh kesalahan membuat model matematika. Karakteristi siswa yang berbeda seringkali menyebabkan jenis kesalahan yang beragam (Zulfah, dkk., 2019). Untuk keperluan perbaikan, kesalahan yang terjadi pada siswa dalam menyelesaikan masalah soal cerita matematika harus diidentifikasi untuk setiap tahapan (Zulyanty, 2019). Kesalahan yang timbul dalam penyelesaian soal matematika didefinisikan sebagai penyimpangan atau kekeliruan jawaban tertulis siswa (Sari, 2018). Bentuk soal cerita kadangkala menjadi masalah yang sulit dipecahkan sebagian siswa karena butuh pemikiran dan pemahaman logis (Budiyono, 2008).

Menurut Ishak dan Warji (1987), faktorfaktor yang menimbulkan kesalahan siswa dalam matematika disebabkan oleh faktor internal dan eksternal. Faktor-faktor internal merupakan faktorfaktor yang berasal dari dalam diri siswa, baik secara biologis maupun psikologis, seperti kecerdasan, fisik, kelemahan, sikap dan kebiasaan. Sedangkan faktor-faktor eksternal berasal dari luar diri siswa, seperti tempat belajar, suasana, cuaca, penerangan, dan pergaulan manusia.

Beberapa hasil penelitian topik yang serupa, seperti Rindyana \& Chandra (2013) dan Rahmania \& Rahmawati (2013) telah menemukan kesalahan pemodelan matematika dari sisi siswa. Pada penyelesaian soal cerita, siswa tidak memahami arti atau maksud kalimat dalam soal, tidak dapat membuat pemodelan matematika yang benar dan kurang teliti dalam menentukan informasi mengenai apa yang diketahui (Rindyana \& Chandra, 2013). Selain itu, siswa melakukan kesalahan dalam memahami konsep, kesalahan dalam menerjemahkan soal ke dalam model matematika, kesalahan dalam menggunakan aturan-aturan atau rumus-rumus matematika, dan kesalahan operasi (Rahmania \& Rahmawati, 2013). Shodikin, dkk. (2019a) mencatat bahwa dua kesalahan berpikir yang paling umum dalam pemodelan matematika adalah membuat asumsi yang tidak tepat dan kegagalan dalam membangun model matematika yang menggambarkan situasi dunia nyata. Gunawan (2016) menyatakan jenis kesalahan yang terjadi adalah memahami soal, membuat pemodelan matematika, melakukan perhitungan, dan penulisan kesimpulan. Kesalahan yang dilakukan siswa tersebut dapat berimbas pada keterampilan siswa menghadapi persoalan nyata di dalam kehidupan sehari-hari. Oleh sebab itu, perlu ada antisispasi atas kesalahan yang dilakukan siswa dengan cara mengidentifikasi kesalahankesalahan tersebut.

Dalam penelitian-penelitian sebelumnya, analisis kesalahan siswa terutama dalam pemodelan matematis masih belum dilengkapi dengan analisis penyebab terjadi kesalahan siswa. Padahal mengetahui penyebab kesalahan siswa 
dalam pemodelan matematis diperlukan untuk memberikan solusi yang tepat dan terukur. Oleh karena itu, untuk mengambil peran itu, tujuan penelitian ini adalah menganalisis kesalahan siswa SMP dalam membuat pemodelan matematika dan faktor-faktor yang menyebabkan terjadinya kesalahan-kesalahan tersebut.

\section{Metode Penelitian}

Penelitian ini merupakan penelitian deskriptif kualitatif dengan tujuan untuk mendeskripsikan kesalahan siswa dalam membuat pemodelan matematika dalam meyelesaiakan soal cerita serta hal-hal yang menyebabkan kesalahan tersebut.

Subjek penelitian ini terdiri dari 3 siswa kelas VIII SMP Negeri 2 Modo, Lamongan, Jawa Timur. Ketiga subjek ini kemudian akan disebut sebagai Subjek 1 (S1), Subjek 2 (S2), dan Subjek 3 (S3). Analisis data dilakukan dengan mengumpulkan data dari satu soal tes pemodelan matematis pada pada materi sistem persamaan linier dua variabel dan wawancara, mentranskrip data hasil wawancara dan mengidentifikasi masalah. Adapun instrumen soal yang digunakan ditunjukkan pada Gambar 1.

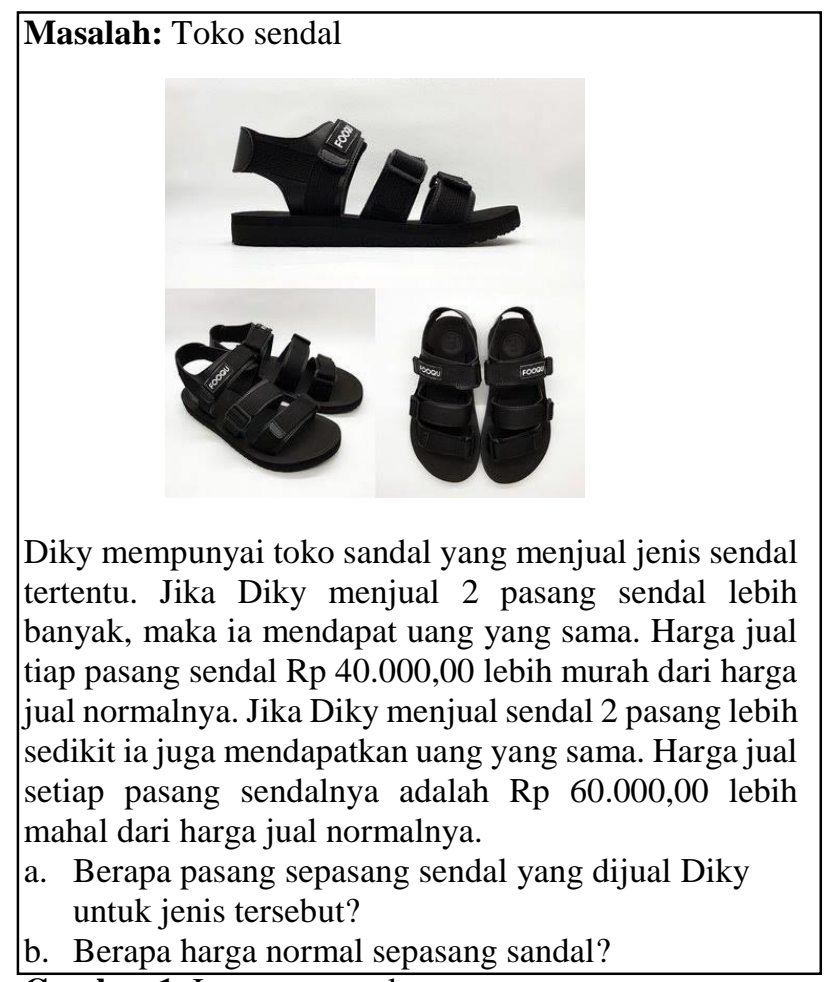

Gambar 1. Instrumen soal

Instrumen pada penelitian ini berupa soal uraian dan pedoman wawancara dalam upaya menggali hal-hal yang yang ingin diketahui dari subjek, dan dokumentasi berupa rekaman serta dokumen jawaban tertulis siswa dalam menyelesaikan suatu soal.

\section{Hasil dan Pembahasan}

Hasil penelitian tentang kemampuan penyelesaian masalah model matematis kontekstual menyatakan bahwa ada beberapa kesalahan yang masih dilakukan siswa dalam membuat pemodelan matematika kesalahankesalan tersenut disebabkan oleh beberapa faktor kesalahan-kesalahan serta faktor penyebabnya dituliskan dalam Tabel 1 berikut.

Tabel 1. Tipe Kesalahan Siswa dalam Menyelesaikan Masalah Pemodelan dan Penyebabnya

\begin{tabular}{|c|c|c|}
\hline No. & Tipe Kesalahan & Penyebab \\
\hline 1 & $\begin{array}{lr}\text { Tidak } & \\
\text { mengidentifikasi } \\
\text { variabel-variabel } \\
\text { pada soal } & \text { sehingga } \\
\text { tidak } & \text { membuat } \\
\text { jawaban } & \text { variabel- } \\
\text { variabel } & \text { untuk } \\
\text { menjadi } & \text { model } \\
\text { matematika } & \\
\end{array}$ & $\begin{array}{l}\text { a. Kesulitan memahami } \\
\text { soal } \\
\text { b. Tidak mengetahui } \\
\text { pemodelan matematika } \\
\text { c. Keterbatasan formasi } \\
\text { terkait pemodelan } \\
\text { matematika untuk } \\
\text { penyelesaian soal }\end{array}$ \\
\hline 2 & $\begin{array}{l}\text { Tidak membuat } \\
\text { asumsi tentang } \\
\text { model yang akan } \\
\text { diformulasikan ke } \\
\text { dalam persamaan }\end{array}$ & $\begin{array}{l}\text { a. Soal yang sangat rumit } \\
\text { b. Kurang Latihan soal } \\
\text { c. Tidak menggunakan } \\
\text { pemodelan matematika } \\
\text { melainkan } \\
\text { menggunakan cara } \\
\text { pemahaman sendiri }\end{array}$ \\
\hline 3 & $\begin{array}{l}\text { Kurang tepat dalam } \\
\text { memformulasikan } \\
\text { dan menyelesaikan } \\
\text { persamaan }\end{array}$ & $\begin{array}{l}\text { a. Soal yang diberi sulit } \\
\text { dipahami } \\
\text { b. Jarang mengerjakan } \\
\text { soal cerita } \\
\text { c. Kurangnya sumber } \\
\text { belajar terkait cara } \\
\text { penyelesaian soal } \\
\text { cerita dengan } \\
\text { pemodelan matematika }\end{array}$ \\
\hline
\end{tabular}

Berdasarkan Tabel 1, dapat diuraikan tipe kesalahan-kesalahan yang dilakukan siswa dalam Menyelesaikan Masalah Pemodelan sebagai berikut.

Kesalahan tipe 1: tidak mengidentifikasi variabel-variabel pada masalah sehingga tidak memiliki jabaran variabel untuk menjadi model

Kesalahan tipe 1 merupakan kesalahan karena subjek tidak menyelesaikan soal dengan mengidentifikasi variabel-variabel yang terdapat pada soal sehingga tidak ada jabaran mengenai variabel untuk menjadi model. Pada kesalahan ini terjadi pada 2 subjek yaitu S2 dan S3. Kesalahan terjadi karena subjek hanya langsung menulis jawabannya saja. Selain itu ada variabel yang dubjek tidan di identifikasi melainkan langsung menulis jawaban pada soal. Ada 1 subjek yaitu S1 
yang lumayan menggunakan pemodelan dan menulis informasi dari soal.

Contoh jawaban subjek yang termasuk dalam kesalahan tipe 1 ditunjukkan pada Gambar 2.

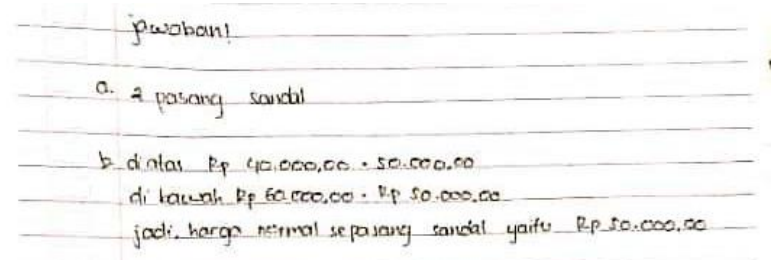

Gambar 2. Hasil jawaban kesalahan tipe 1 yang tidak mengidentifikasi variabel-variabel yang ada

Kemudian wawancara untuk mengetahui penyebab kesalahan dalam pengerjaan soal tersebut. Didapatkan hasil bahwa kesalahan terjadi karena soal yang diberikan terlalu rumit. Selain itu siswa menggunakan nalar atau cara sendiri untuk mengetahu jawaban dari soal tersebut. Hal tersebut dapat dilihat dari wawancara berikut.

P : Apakah kamu pernah menyelesaikan soal seperti ini?

S2 : Nggak tau lupa mbk

$\mathrm{P} \quad$ : Apakah soal tersebut susah?

S2 : Susah baget mbk

$\mathrm{P}$ : Bagaimana pengerjaannya dan cara apa yang kamu gunakan?

S2 : nggak ada cara dalam matematika yang saya gunakan, yang saya gunakan cara saya sendiri

Wawancara dengan subjek S2 tersebut mendapatkan jawaban bahwa subjek memang tidak mengetahui tentang pentingnya pemodelan matematika, lebih sering menggunakan cara nalar dan jarang Latihan soal certia. Selain itu subjek merasa bingung dengan soal tersebut karena soal sangat rumit dan susah dipahai oleh subjek. Jadi aktifitas mengerjakan soal dengan menggunakan pemodelan matematika sangat sangat rendah.

\section{Kesalahan tipe 2: Tidak membuat asumsi tentang model yang akan diformulasikan ke dalam persamaan}

Kesalahan tipe 2 kesalahan dalam subjek tidak membuat asumsi mengenai model yang akan dibentuk ke dalam persamaan. Pada tipe kesalahan 2 ini terjadi pada 3 subjek yaitu S1, S2, S3 melakukan kesalahan tipe 2 ini karena memang melakukan tipe kesalahan 1 karena tidak menjabarkan variabel-variabel untuk menjadi model sehingga tidak ada model yang diasumsikan. Pada subjek lain kesalahan terjadi karena menyelesaikan soal langsung mengoprasikan variabel yang dituliskannya tanpa membuat asumsi mengenai model terlebih dahulu.

Contoh jawaban subjek yang termasuk ke dalam kesalahan tipe 2 ditunjukkan pada Gambar 3.

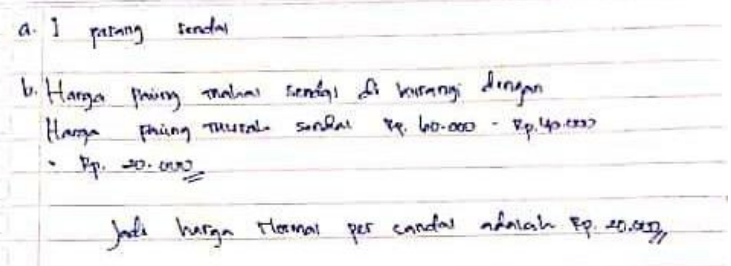

Gambar 3. Hasil jawaban kesalahan tipe 2 tidak membuat asumsi tentang model yang akan diformulasikan

Berdasarkann wawancara untuk mengetahui penyebab kesalahan dalam pengerjaan soal tersebut, didapatkan hasil bahwa kesalahan terjadi karena soal yang diberikan terlalu rumit. Selain itu siswa menggunakan nalar atau cara sendiri untuk mengetahu jawaban dari soal tersebut. Hal tersebut dapat dilihat dari wawancara berikut.

$$
\begin{array}{ll}
\text { P } & : \begin{array}{l}
\text { Bagaimana cara pemodelan yang kamu } \\
\text { buat? }
\end{array} \\
\text { S3 : } & \begin{array}{l}
\text { Enggak ada dan nggak tau intinya saya } \\
\text { sudah mengerjakan }
\end{array} \\
\text { P } & : \text { Kenapa? } \\
\text { S3 : Susah baget mbak }
\end{array}
$$

Wawancara dengan subjek S3 tersebut mendapatkan jawaban bahwa subjek memang tidak membuat asumsi mengeni model matemaatis, dan subjek mengatakan bahwa tidak melakukan hal tersebut karena soal yang diberikan terlalu sulit untuk dipahami dan jarang mengerjakan Latihan soal.

\section{Kesalahan tipe 3: Kurang tepat dalam memformulasikan dan menyelesaikan persamaan}

Kesalahan tipe 3 adalah kesalahan dalam memformulasikan dan menyelesaikan persamaan matematika. Kesalahan terjadi pada 3 subjek yang terdiri dari S1, S2, S3 melakukan kesalahan ini tidak membuat asumsi model yang diketahui pada soal sehingga tidak ada yang diformulasikan ke dalam persamaan tetapi pada subjek S1 subjek membuat pemodelan dengan mencatat informasi yang ada pada soal tetapi pada saat memformulasikan ke dalam persamaan kurang tepat.

Contoh jawaban subjek yang termasuk ke dalam kesalahan tipe 3 ditunjukkan pada Gambar 4. 


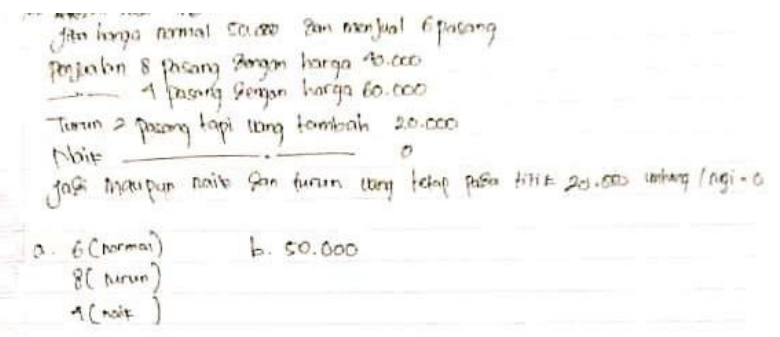

Gambar 4. Hasil jawaban kesalahan tipe 3 yang kurang tepat memformulasikan ke dalam persamaan

Kemudian wawancara terhadap subjek menunjukkan faktor yang mempengaruhi terjadinya kesalahan tersebut karena soal yang diberikan terlalu sulit, kurangnya sumber belajar dan kurangnya latiahan mengerjakan soal-soal. Hal tersebut dapat dilihat pada hasil wawancara subjek sebagai berikut.

$\begin{array}{ll}\mathrm{P} & : \text { Bagaimana kamu mendapatkan jawaban } \\ & \text { seperti itu? } \\ \mathrm{S} 1 \quad: \quad \begin{array}{l}\text { Dengan cara itu yang ada dalam pikiran } \\ \text { saya ya persamaan mbak }\end{array} \\ \mathrm{P} \quad: \begin{array}{l}\text { Apakah kamu yakin dengan jawabanmu } \\ \text { itu? }\end{array} \\ \mathrm{S} 1 \quad: \quad \text { Iya yakin }\end{array}$

Wawancara dengan subjek S1 tersebut mendapatkan jawaban bahwa subjek memang kesulitan dalam mengerjakan soal yang diberikan dan ketiga subjek juga belum memahami seberapa pentingnya menggunakan pemodelan saat menyelesaikan soal.

Berdasarkan analisis data dan wawancara ketiga subjek dapat diketahui bahwa subjek tidak dapat menyelesaikan masalah pada soal tersebut dengan baik karena ketiga subjek sulit untuk memahami soal yang diberikan dan tidak memahami pula tentang pemodelan matematika. Penelitian Shodikin, dkk. (2019a) menguatkan hasil temuan ini yang menunjukkan seringnya siswa membuat asumsi yang tidak tepat terhadap masalah yang dihadapi. Hal ini menyebabkan aktivitas dalam mengerjakan soal juga kurang maksimal. Dalam penelitian ini kemampuan dan aktivitas untuk menyelesaikan masalah model matematis masih sangat kurang baik, dan juga masih sering menggunakan penalaran sendiri dan caranya sendiri-sendiri karena soal yang diberikan terlalu rumit.

Temuan penelitan ini juga didukung hasil penelitian Nugroho (2007) yang menunjukkan bahwa salah satu faktor yang mempengaruhi kesalahan siswa dalam menyelesaikan soal cerita adalah siswa belum mampu menerjemahkan soal ke dalam model matematika. Selain itu, penelitian yang dilakukan oleh Rindyana dan Chandra (2013) juga menunjukkan bahwa kesalahan yang berasal dari siswa disebabkan karena siswa tidak memahami arti atau maksud kalimat dalam soal, tidak dapat mentransformasikan apa yang mereka ketahui ke dalam kalimat matematika yang benar dan kurang teliti dalam menentukan informasi mengenai apa yang diketahui. Dalam penelitian ini ditemukan bahwa siswa belum mampu menerjemahkan soal ke dalam model matematika. Hasil yang sama ditunjukkan oleh penelitian Shodikin, dkk. (2019a) yang menunjukkan kesalahan dalam pemodelan matematika diantaranya kegagalan dalam membangun model matematika yang menggambarkan situasi dunia nyata. Senada dengan hal ini juga disampaikan oleh Gunawan (2016). Hal ini dimungkinkan karena siswa tidak mengetahui tentang pemodelan matematika, jarang mengerjakan latihan soal cerita, sering menggunakan cara nalar sendiri atau coba-coba, soal yang diberikan terlalu rumit serta kurangnya sumber belajar siswa terlebih tentang pemodelan matematika untuk menyelesaikan soal cerita.

Untuk menanggulangi masalah-masalah ini, sebaiknya pemberian soal-soal pemodelan matematis dalam proses pembelajaran perlu ditambahkan oleh guru baik untuk mengajarkan konsep tertentu maupun sebagai soal latihan dan tes pemecahan masalah matematis. Soal-soal pemodelan matematis non rutin juga sebaiknya diberikan sehingga siswa tidak terikat pada satu jenis masalah tertentu maupun satu prosedur penyelesaian masalah tertentu. Pembelajaran yang mengedepankan peningkatan inkuiri siswa juga perlu digalakkan untuk menambah kemampuan berpikir kritis dan kreatif siswa dalam menyelesaikan masalah pemodelan matematis. Selain itu pendekatan kontekstual yang melibatkan kehidupan sehari-hari juga perlu diterapkan. Hal ini didukung pendapat Nurhadi (2014) bahwa tanpa melibatkan kehidupan sehari-hari maka siswa akan cepat lupa dan tidak dapat mengaplikasikan matematika.

\section{Kesimpulan}

Kesalahan siswa dalam membuat pemodelan adalah siswa tidak mengidentifikasi variablevariabel yang terdapat dalam soal sehingga siswa tidak dapat menyelesaikan masalah dalam soal tersebut. Kesalahan yang berasal dari faktor internal diantaranya siswa kurang mengerjakan latihan soal-soal cerita, tidak mengetahui apa itu pemodelan matematis dan pentingnyaa pemoddelan matematika untuk menyelesaikan soal cerita. Sedangkan kesalahan faktor eksternal diantaranya soal yang diberikan terlalu sulit 
dipahami oleh siswa dan kurangnya sarana prasarana penunjang seperti buku dan sumber lainnya.

Selanjutnya, bagi guru dan calon guru, hendaknya lebih memperhatikan cara siswa menyelesaikan soal dan sarana prasana untuk menunjang proses pembelajaran. Untuk siswa hendaknya lebih sering mengerjakan latihanlatihan soal dan meningkatkan pemahaman dalam menyelesaikan soal-soal matematika.

\section{Daftar Pustaka}

Amala, M. A \& Ekawati, R. (2016). Profil Proses Matematisasi Horizontal dan Vertikal Siswa Smp Dalam Menyelesaikan Masalah Kontekstual Pecahan Ditinjau dari Kemampuan Matematika. MATHEdunesa Jurnal Ilmiah Pendidikan Matematika, 3(5), 301-309.

Ang, K. C. (2001). Teaching mathematical modelling in Singapore schools. The Mathematics Educator, 6(1), 63-75. Retrieved from https://repository.nie.edu.sg/handle/10497/49

Budiyono. (2008). Kesalahan Mengerjakan Soal Cerita dalam Pembelajaran Matematika. Jurnal Pedagogia, 11(1), 1-8.

Dym, C. L., \& Ivey, E. S. (2004). Principles of Mathematical Modeling. Amsterdam: Elsevier

Gunawan, A. (2016). Analisis Kesalahan dalam Menyelesaikan Soal Cerita Pada Mata Pelajaran Matematika Siswa Kelas V SDN 59 Kota Bengkulu. Jurnal PGSD: Jurnal Ilmiah Pendidikan Guru Sekolah Dasar, 9(2), 216-255.

Ischak dan Warji. (1987). Program Remedial dalam Proses Belajar Mengajar. Yogyakarta: Liberty

Ndii, M. Z. (2018). Pemodelan Matematika. Yogyakarta: Penerbit Depublish.

Nugroho, F. A. (2017). Kemampuan Siswa Menyelesaikan Soal Cerita SPLDV Ditinjau dari

Taksonomi Solo Kelas X. Universitas Muhammadiyah Surakarta.

Nuryadi. (2014). Keefektifan Pendekatan CTL dan PPM Pembelajaran Matematika Metode GTG Ditinjau Keaktifan dan Prestasi Siswa Effectiveness of CTL Approach and PPM with GTG Method on Mathematics Teaching in Terms of Learning Activeness and Achievement of the Students. PYTHAGORAS: Jurnal Pendidikan Matematika, 9(1), 22-30.
Rahmania, L., \& Rahmawati, A. (2013). Analisis Kesalahan Siswa dalam (Analysis of Student'S Errors in Solving Word Problems. Darul Ulum, 1(2), 165-174

Rahmawati, F. (2013). Pengaruh Pendekatan Pendidikan Realistik Matematika dalam Meningkatkan Kemampuan Komunikasi Matematis Siswa Sekolah Dasar. Prosiding

SEMIRATA 2013, 1(1), 225-238. http://jurnal.fmipa.unila.ac.id/index.p $\mathrm{hp} / \mathrm{semirata} /$ article/view/882

Rindyana, B. S. B., \& Chandra, T. D. (2013). Analisis Kesalahan Siswa dalam Menyelesaikan Soal

Cerita Matematika Materi Sistem Persamaan Linear Dua Variabel Berdasarkan Analisis Newman.

Sari, P. R. (2018). Analisis Kesalahan Siswa SMP dalam Menyelesaikan Soal SPLDV. Prosiding Seminar Nasional Etnomatnesia.

Shodikin, A., Istiandaru, A., Purwanto, Subanji \& Sudirman (2019a, March). Thinking errors of pre-service mathematics teachers in solving mathematical modelling task. In Journal of Physics: Conference Series (Vol. 1188, No. 1, p. 012004). IOP Publishing.

Shodikin, A., Novianti, A., \& Sumarno, W. K. (2019b, February). Mathematics pre-service teachers' thinking process in solving modeling task in differential calculus course. In Journal of Physics: Conference Series (Vol. 1157, No. 2, p. 022127). IOP Publishing.

Widowati, \& Sutimin. (2007). Buku Ajar Pemodelan Matematika. Semarang: FMIPA Universitas Diponegoro.

Zulfah. (2017). Analisis Kesalahan Peserta Didik pada Materi Persamaan Linear Dua Variabel di

Kelas VIII MTS Negeri Sungai Tonang. Journal Cendekia: Jurnal Pendidikan Matematika, 1(1), $12-16$

Zulfah, Astuti, Insani, S. U., Zulhendri, \& Akbar, P. (2019). Development of Open-Ended Based

Mathematics Problem to Measure High-Level Thinking Ability Development of Open-Ended

Based Mathematics Problem to Measure High-Level Thinking Ability. Journal of Physics:

Conference Series, 0-8. https://doi.org/10.1088/17426596/1315/1/012047

Zulyanty, M. (2019). Newman Error Analysis Siswa Madrasah dalam Menyelesaikan Soal Cerita Matematika. Jurnal Cendekia: Jurnal Pendidikan Matematika, 3(2), 379-388. https://doi.org/10.31004/cendekia.v3i2.121 